\title{
Fibrosis Development, Leukemic Transformation and Secondary Malignancies Complicating the Clinical Course of Essential Thrombocythemia
}

\author{
Rafiye CIFTCILER ${ }^{1}$, Salih AKSU ${ }^{1}$, Umit Yavuz MALKAN ${ }^{2}$,

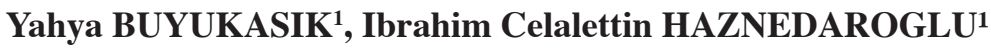 \\ ${ }^{1}$ Hacettepe University, Faculty of Medicine, Department of Hematology \\ ${ }^{2}$ Diskapı Education and Research Hospital, Department of Hematology, Ankara, TURKEY
}

\begin{abstract}
Essential thrombocythemia (ET) is a myeloproliferative neoplastic disease characterized by abnormal proliferation of megakaryocytes in the bone marrow leading to elevated platelet counts in the peripheral blood. In the present study, we aim to assess the long-term complications of ET and its treatments in terms of the development of secondary malignancies, bone marrow fibrosis and leukemic transformation. One hundred and twenty four patients with ET were included into the study. Retrospective data were collected from our database of myeloproliferative disorders. There were 75 (60.5\%) men and 49 (39.5\%) women with a median age of 53 (range, 20-80) years. The data indicated that 3 patients treated with hydroxyurea (HU) had suffered of bladder cancer, non-small cell lung cancer and thyroid papillary cancer, 2 patients without treatment suffered of breast cancer and neuroendocrine cancer and 2 patients treated with combination (HU and anagrelide) suffered of acute myeloid leukemia (AML) and prostate cancer. In total, 16/124 patients (12.9\%) developed bone marrow fibrosis. Nine of the patients (7.2\%) who developed bone marrow fibrosis were receiving HU, 5 of them (4\%) were using $\mathrm{HU}$ and anagrelide and 2 of them (1.6\%) were followed without treatment $(p=0.44)$. The age $(p=0.03)$, hemoglobin level at diagnosis $(p<0.001)$, white blood cell level at diagnosis $(p=0.02)$, CRP level $(p=0.01)$, pre-treatment hemorrhage rate $(p<0.001)$ were statistically significant different between the patients who developed myelofibrosis and patients who did not develop myelofibrosis. The results of this study disclosed that there was no statistically significant difference regarding the development of bone marrow fibrosis, leukemic transformation or secondary malignancies with regard to the treatment options of ET. Moreover, ET patients who had received $\mathrm{HU}$ and anagrelide treatment has better OS than the other patient cohorts.
\end{abstract}

Keywords: Essential thrombocythemia, Myelofibrosis, Secondary malignancy, Hydroxyurea, Acute myeloid leukemia

ÖZET

Esansiyel Trombositozun Klinik Seyrini Oluşturan Fibrozis Gelişimi, Lösemik Dönüşüm ve Sekonder Malignitelerin Değerlendirilmesi

Esansiyel trombositemi (ET), periferik kanda trombosit sayısında artışa yol açan kemik iliğinde anormal megakaryosit proliferasyonu ile karakterize miyeloproliferatif bir neoplastik hastalıktır. Bu çalışmada ET'nin uzun süreli komplikasyonlarını ve tedavilerini sekonder maligniteler, kemik iliği fibrozu ve lösemi transformasyonu açısından değerlendirmeyi amaçladık. ET’li 124 hasta çalışmaya dahil edildi. Retrospektif veriler, myeloproliferatif hastalıklar veritabanımızdan edinilmiştir. Hastaların ortanca yaşı 53 (20-80) saptandı. Çalışmaya 75 (\%60.5) erkek ve 49 (\% 39,5) kadın dahil edildi. Hidroksiüre (HU) ile tedavi edilen 3 hastada mesane kanseri, küçük hücreli dışı akciğer kanseri ve tiroid papiller kanseri gözlendi. Tedavi almayan 2 hastada meme kanseri ve nöroendokrin kanseri gelişti. Hidroksiüre ve anagrelide alan 2 hastada AML ve prostat kanseri izlendi. Toplamda 16 hastada (\%12.9) kemik iliği fibrozu gelişti. Kemik iliği fibrozisi gelişen hastaların 9'u (\%7.2) HU, 5’i (\% 4) HU ve anagrelid kullanıyordu, 2 (\%1.6) hasta ise ilaçsız takip ediliyordu ( $p=0.44)$. Yaş $(p=0.03)$, tanıdaki hemoglobin düzeyi $(p<0.001)$, beyaz küre sayısı $(p=0.02)$, CRP düzeyi $(p=0.01)$ ve tedavi başlanmadan önceki kanama oranı $(p<0.001)$ takipte myelofibrosis gelișen hastalarla, myelofibrosis gelişmeyen hastalar arasında istatistiksel olarak anlamlı farkllık gözlendi. Bu çalışmanın sonuçları, ET'de tedavi seçenekleri açısından kemik iliği fibrozu, lösemik transformasyon veya sekonder malignite gelişimi açısından istatistiksel olarak anlamlı bir fark olmadığını ortaya koydu. Ayrıca, HU ve anagrelid tedavisi alan ET hastaları diğer hasta gruplarından daha iyi OS'ye sahipti.

Anahtar Kelimeler: Esansiyel trombositoz, Myelofibrosis, Sekonder malignite, Hidroksiüre, Akut myeloid lösemi

ORCIDs: Rafiye CIFTCILER: 0000-0001-5687-8531 Yahya BUYUKASIK: 0000-0002-2700-295X 


\section{INTRODUCTION}

Essential thrombocythemia (ET) is a chronic myeloproliferative disorder (CMPD) characterized by the abnormal proliferation of neoplastic megakaryocytes in the bone marrow (BM) leading to the elevated platelet counts in the circulating blood. ${ }^{1}$ ET is commonly occurred in elderly patients associated with major and/or minor vascular complications leading to the increased morbidity and even mortality. ${ }^{2,3}$ The patients with ET are at clinical risk for a number of adverse complicating clinical outcomes including hemorrhage, thrombosis and progression to fibrosis or acute myeloid leukemia (AML). ${ }^{4}$ Increased platelet counts are associated with an increased risk of bleeding, microvascular occlusion and clinical thrombosis. ${ }^{5,6}$ Cytoreduction is indicated in patients with previous thrombosis in patients above 60 years of age or a platelet count more than $1500 \times 10^{9} / \mathrm{L}^{7}$ Cytoreductive treatment with or without low-dose aspirin, is the main approach for the of thrombotic risk reduction. Several drugs, such as hydroxyurea (HU), anagrelide, interferon and busulfan are the options for the management. ${ }^{1,89}$ Anagrelide has been an option for the treatment of thrombocytosis in CMPD, although $\mathrm{HU}$ is practically considered to be the first drug of choice. ${ }^{10} \mathrm{HU}$ is the preferred cytoreductive agent for most of the ET patients. HU is effective at reducing platelet counts and thrombotic risk in ET. The drug is generally well tolerated and widely available. ${ }^{9}$ Anagrelide is a non-cytostoxic drug with a selective megakaryocyte effect restricted to the reducing platelets via inhibiting the BM megakaryocyte maturation. ${ }^{11}$

In the present study, we assessed the long-term efficacy and clinical toxicity of the treatment modalities in patients with ET in terms of the development of secondary malignancy, myelofibrosis and leukemic transformation.

\section{PATIENTS AND METHODS}

\section{Study Design and Data Collection}

This study has been performed in a retrospective manner. In total, 124 patients with ET were included in to the study. The patients diagnosed as ET, according World Health Organization (WHO)
2016 criteria. ${ }^{12}$ The patients who diagnosed in our hematology clinic at Hacettepe University Hospital were evaluated. Taking in consideration the different treatment approaches, we separated our ET patients in to five different groups: group 1, only follow up, 'none treatment' patients; group 2, patients treated with only $\mathrm{HU}$; group 3 , patients treated with only anagrelide; group 4 , patients treated with $\mathrm{HU}+$ anagrelide; group 5, patients treated with $\alpha$ - interferon (IFN). All of the clinical data were collected from our MPD database in Hematology clinic. As a result of the general application standards of the hospitals of Hacettepe Medical School, it has been recognized from the patient records and database that all of the studied patients had given informed consents at the time of hospital admission and before the administration of chemotherapy and before other relevant diagnostic/therapeutic standards of care. This study was approved by the Ethical Committee of the Hacettepe University (05.02.2019 GO19/146).

\section{Statistical Analyses}

Statistical analyses were performed using the SPSS software version 25 . The variables were investigated using visual (histograms, probabilty plots) and analytical methods (Kolmogorow-Simirnov/ Shapiro-Wilk's test) to determine whether they are normally distributed or not. Statistical comparisons were made using Chi-square for categorical data. Student's t test (for two independent samples) was used for comparison of continuous numerical data. Survival analyses were made using KaplanMeier test. Time free to the secondary malignancy/ myelofibrosis/AML was calculated by the KaplanMeier method since date of therapy start, or diagnosis for no therapy patients until development of secondary malignancy/myelofibrosis/AML or last follow up. Multivariate analysis of the predictors of survival was performed using Cox regression test. Parameters with $\mathrm{P}$ values $\leq 0.10$ in univariate tests were included in the multivariate analysis. $\mathrm{P}$ values $<0.05$ were considered to indicate statistical significance. We considered exposure time as the period passing between start of treatment and the last application of the drug. 
Table 1. Characteristics of the essential thrombocythemia patients

\section{Characteristics of patients}

The median age (range)

$53(20-80)$ years

Male/female (\%)

$75 / 49(60.5 / 39.5 \%)$

Hemoglobin at diagnosis (g/dl) (range) 13.9 (7-17)

Leukocyte at diagnosis $10^{3} \mathrm{\mu l}$ (range)

$10.2(4.9-31.8)$

Thrombocyte at diagnosis $10^{3} \mu \mathrm{l}$ (range)

$\mathrm{MCV}$ (fL) at diagnosis

807 (343-2824)

CRP at diagnosis ( $\mathrm{mg} / \mathrm{dl})$ (range)

$87(56-127)$

$\mathrm{LDH}$ at diagnosis (u/lt) (range)

$0.4(0.1-23)$

Splenomegaly (\%)

$482(141-2343)$

JAK2V617F mutation positivity

$36(29 \%)$

$68(54.8 \%)$

Abbreviations: MCV, mean corpuscular volume; CRP, C-reactive protein; LDH, lactate dehydrogenase

\section{RESULTS}

\section{Patient Population}

A total of 124 patients were entered into the study between 2001 and 2015. The patients with median follow-up of less than 36 months were excluded from the study in order to detect development of secondary malignancy, myelofibrosis and AML in the follow-up of patients. Patient characteristics are summarized in Table 1. There were 75 (60.5\%) males and $49(39.5 \%)$ females with a median age of 53 (range, 20-80) years at the time of diagnosis. We grouped all patients: group 1, no treated patients (28 patients $22.6 \%$ ); group 2, patients treated with only HU (46 patients $37.1 \%$ ); group 3, patients treated with only anagrelide (4 patients $3.2 \%$ ); group 4, patients treated with $\mathrm{HU}+$ anagrelide (43 patients $34.7 \%$ ); group 5 , patients treated with $\alpha$ interferon (IFN) (3 patients 2.4\%). In all, 96/124 patients $(77.4 \%)$ were tested for JAK2V617F and $54.8 \%$ (68 patients) resulted positive. As regard cardiovascular risk factors, we evaluated the presence of smoking, hypertension, dyslipidemia, and diabetes. At least one risk factor was observed in $40.3 \%(50 / 124)$ of patients and $59.6 \%$ of patients (74/124) did not have any cardiovascular risk factors. In total, 25/124 patients (20.1\%) had constitutional symptoms at the diagnosis. In all, 36/124 patients (29\%) had splenomegaly at the diagnosis.

\section{Disease Transformation and Secondary Malignancies}

In total, 6/124 patients (4\%) developed secondary malignancy such as prostate cancer (1 patient, $0.8 \%$ ), non-small cell lung cancer ( 1 patient, $0.8 \%$ ), bladder cancer ( 1 patient, $0.8 \%$ ), thyroid papillary cancer (1 patient, $0.8 \%$ ), breast cancer (1 patient, $0.8 \%$ ), neuroendocrine cancer (1 patient, $0.8 \%$ ). We observed that 3 patients treated with HU suffered of bladder cancer, non-small cell lung cancer and thyroid papillary cancer, 2 patients without treatment suffered of breast cancer and neuroendocrine cancer, 2 patients treated with $\mathrm{HU}$ and anagrelide suffered of AML and prostate cancer. In all, 16/124 patients (12.9\%) developed myelofibrosis. Nine of the patients $(7.2 \%)$ who developed myelofibrosis were using HU, 5 of them (4\%) were using HU and anagrelide, and 2 of them (1.6\%) were followed without treatment (Table 2). Cumulative incidence plot of myelofibrosis according to treatment groups

\begin{tabular}{|c|c|c|c|c|c|c|}
\hline Group & No therapy & HU & Anagrelide & HU+Anagrelide & IFN & $\mathbf{p}$ \\
\hline $\mathrm{N}(\%)$ & $28(22.6 \%)$ & $46(37.1 \%)$ & $4(3.2 \%)$ & $43(34.7 \%)$ & $3(2.4 \%)$ & \\
\hline Pre-treatment thrombosis (\%) & 0 & $15(32.6 \%)$ & 0 & $12(28 \%)$ & 0 & \\
\hline Pre-treatment hemorrhage (\%) & 0 & $7(15.2 \%)$ & 0 & $7(16.3 \%)$ & 0 & \\
\hline AML transformation & 0 & 0 & 0 & $1(2.3 \%)$ & 0 & 0.75 \\
\hline Myelofibrosis transformation & $2(7.1 \%)$ & $9(19.6 \%)$ & 0 & $5(11.6 \%)$ & 0 & 0.44 \\
\hline Secondary malignancy & $2(7.1 \%)$ & $3(6.5 \%)$ & 0 & $1(2.3 \%)$ & 0 & 0.87 \\
\hline Mortality rate (\%) & $7(25 \%)$ & $14(30.4 \%)$ & $1(25 \%)$ & $10(23.3 \%)$ & 0 & 0.78 \\
\hline
\end{tabular}




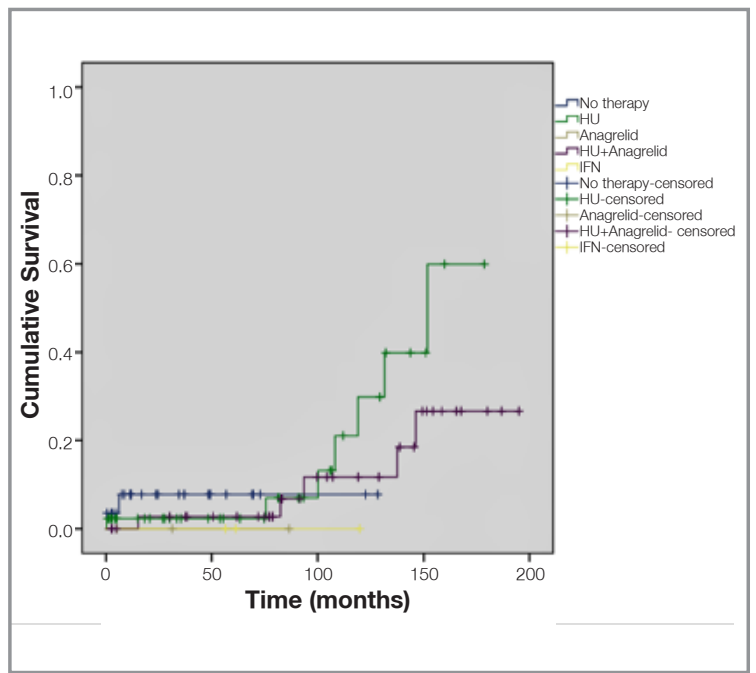

Figure 1. Cumulative incidence plot of bone marrow fibrosis according to the treatment groups in essential thrombocythemia $(p=0.11)$

was shown in Figure 1. There was no significant difference in mortality rates between five groups $(p=0.78)$, however there was not seen any mortality in patients who received IFN. Reports of leukemic transformation, myelofibrosis transformation,

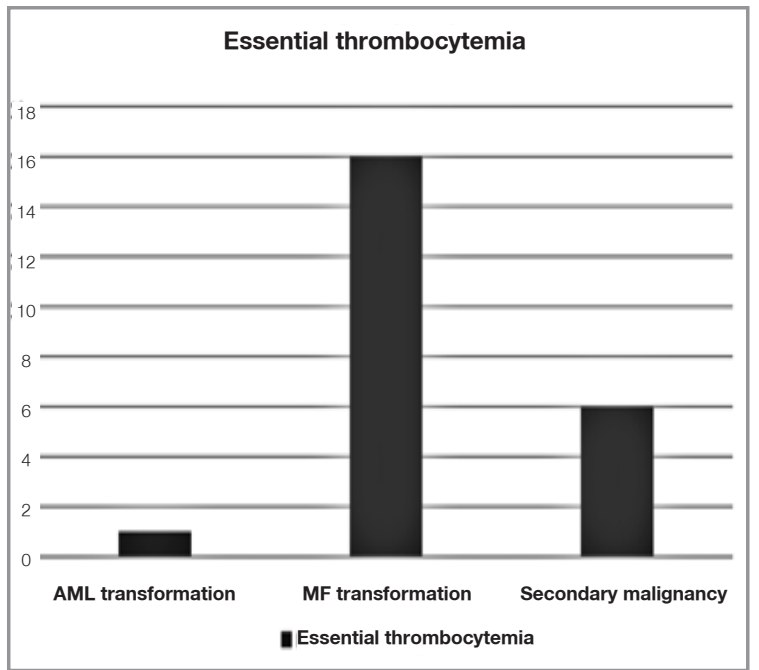

Figure 2. Reports of acute myeloid leukemia (AML) transformation, myelofibrosis (MF) transformation, secondary malignancy development in our patient cohort with essential thrombocythemia patients

secondary malignancy development and number of deaths were shown in Figure 2.

There were 16 patients (12.9\%) who developed myelofibrosis during follow-up. The age $(\mathrm{p}=0.03)$, hemoglobin level at diagnosis $(p<0.001)$, white

Table 3. Characteristics of essential thrombocythemia patients who developed myelofibrosis and who did not develop myelofibrosis

\begin{tabular}{|c|c|c|c|}
\hline Parameters & Patients who developed & Patients who did not develop & $\mathbf{p}$ \\
\hline $\mathrm{N}(\%)$ & $16(12.9 \%)$ & $108(87.1 \%)$ & \\
\hline The median age (range) & $63(20-78)$ & $52(20-80)$ & 0.03 \\
\hline Male/female (\%) & $6 / 10(37.5 \% / 62.5 \%)$ & $43 / 65$ (39.8/60.2\%) & 0.86 \\
\hline Hemoglobin* at diagnosis (gr/dl) (range) & $11(8-15)$ & $14(7-17)$ & $<0.001$ \\
\hline Leukocyte* at diagnosis 103 $\mu$ l (range) & $13.9(7-31.8)$ & $10.1(4.9-31)$ & 0.02 \\
\hline Thrombocyte $^{\star}$ at diagnosis $103 \mu \mathrm{l}$ (range) & $832(381-2.428)$ & 789 (343-2.824) & 0.9 \\
\hline $\mathrm{MCV}^{\star}$ (fL) at diagnosis & $92(78-109)$ & $86(56-127)$ & 0.39 \\
\hline $\mathrm{CRP}^{\star}$ at diagnosis (mg/dl) (range) & $2.8(0.2-11.2)$ & $0.4(0.1-23)$ & 0.01 \\
\hline $\mathrm{LDH}^{\star}$ at diagnosis (u/lt) (range) & $703(382-1580)$ & $471(141-2343)$ & 0.06 \\
\hline Splenomegaly* (\%) & $8(50 \%)$ & 28 (25.9\%) & 0.04 \\
\hline JAK2V617F mutation positivity & 9 (56.3\%) & 59 (56.4\%) & 0.91 \\
\hline Pre-treatment thrombosis (\%) & 5 (31.3\%) & $22(20.4 \%)$ & 0.32 \\
\hline Pre-treatment hemorrhage (\%) & $5(31.3 \%)$ & $9(8.3 \%)$ & $<0.001$ \\
\hline Mortality rate (\%) & $9(56.3 \%)$ & $21(21.3 \%)$ & $<0.001$ \\
\hline Patients who received HU & $14(87.5 \%)$ & 75 (69.4\%) & 0.13 \\
\hline Patients who received Anagrelide & 5 (33.3\%) & $40(37 \%)$ & 0.78 \\
\hline
\end{tabular}




\begin{tabular}{|c|c|c|c|}
\hline Parameters & $\begin{array}{l}\text { Patients who developed } \\
\text { secondary malignancy }\end{array}$ & $\begin{array}{l}\text { Patients who did not develop } \\
\text { secondary malignancy }\end{array}$ & $\mathbf{p}$ \\
\hline $\mathrm{N}(\%)$ & 7 (5.6\%) & $117(94.4 \%)$ & 0.39 \\
\hline The median age (range) & $58(42-74)$ & $53(20-80)$ & 0.23 \\
\hline Male/female (\%) & $3 / 4(42.9 / 57.1 \%)$ & 46/71 (39.3/60.7\%) & 0.85 \\
\hline Hemoglobin* at diagnosis (gr/dl) (range) & $14(7-17)$ & $14(8-17)$ & 0.96 \\
\hline Leukocyte* at diagnosis $10^{3} \mu \mathrm{l}$ (range) & $7.9(4.9-21.6)$ & $10.3(5.7-31.8)$ & 0.51 \\
\hline Thrombocyte ${ }^{\star}$ at diagnosis $10^{3} \mu \mathrm{l}$ (range) & $742(519-1.210)$ & $809(343-2.824)$ & 0.39 \\
\hline $\mathrm{MCV}^{*}$ (fL) at diagnosis & 87 (76-102) & $86(56-127)$ & 0.54 \\
\hline $\mathrm{CRP}^{\star}$ at diagnosis (mg/dl) (range) & $0.3(0.1-0.7)$ & $0.5(0.1-23)$ & 0.05 \\
\hline $\mathrm{LDH}^{\star}$ at diagnosis (u/lt) (range) & $447(310-584)$ & $482(141-2343)$ & 0.52 \\
\hline JAK2V617F mutation positivity & $3(42.9 \%)$ & $65(55.6 \%)$ & 0.41 \\
\hline Splenomegaly ${ }^{\star}(\%)$ & 3 (42.9\%) & $33(28.2 \%)$ & 0.40 \\
\hline Pre-treatment thrombosis (\%) & $1(14.3 \%)$ & $26(22.2 \%)$ & 0.62 \\
\hline Pre-treatment hemorrhage (\%) & $1(14.3 \%)$ & $13(11.1 \%)$ & 0.79 \\
\hline Mortality rate (\%) & $3(42.9 \%)$ & $29(24.8 \%)$ & 0.28 \\
\hline Patients who received HU & 5 (71.4\%) & $84(71.8 \%)$ & 0.98 \\
\hline Patients who received Anagrelide & $1(14.3 \%)$ & $44(37.9 \%)$ & 0.2 \\
\hline
\end{tabular}

blood cell level at diagnosis $(p=0.02)$, CRP level $(p=0.01)$, pre-treatment hemorrhage rate $(\mathrm{p}<$ 0.001 ) were statistically significant different between the patients who developed myelofibrosis and patients who did not develop myelofibrosis as shown in Table 3. The mortality rate was statistically significant higher in patients who developed myelofibrosis than patients who did not develop myelofibrosis $(\mathrm{p}<0.001)$. There was no statistically significant relationship between the use of $\mathrm{HU}$ $(\mathrm{p}=0.13)$ or anagrelide $(\mathrm{p}=0.78)$ and myelofibrosis development. No statistically significant difference was found the parameters shown in Table 4 between the patients who developed secondary malignancy and who did not develop secondary malignancy. There was no statistically significant relationship between the use of $\mathrm{HU}(\mathrm{p}=0.98)$ or anagrelide $(\mathrm{p}=$ 0.2 ) and secondary malignancy development. The diagnosis of the patients with CMPD were confirmed via performing histopathological analyses. BM megakaryocytes in normal hematopoiesis and neoplastic megakaryocytes of essential thrombocythemia were depicted in Figure 3.

\section{Overall Survival}

Median follow-up of the entire group was 69.3 months $(0.3$ - 194.9). The 3 -year OS for patients who did not treated was $78 \%$, patients who treated with $\mathrm{HU}$ was $80 \%$, patients who treated with anagrelide was $50 \%$, patients who treated with $\mathrm{HU}$ and anagrelide was $94 \%$ and patients who treated with IFN was $100 \%$, respectively. The 5-year OS for patients who did not treated was $68 \%$, patients who treated with $\mathrm{HU}$ was $74 \%$, patients who treated with anagrelide was $50 \%$, patients who treated with $\mathrm{HU}$ and anagrelide was $91 \%$ and patients who treated with IFN was $100 \%$, respectively $(\mathrm{p}=0.02)$ as shown in Figure 4.

\section{DISCUSSION}

Thrombocytosis is a characteristics anomaly in patients with CMPD and is the definitive finding of ET. Cytoreductive therapies are the basis for the management of ET however, the data clearly demonstrating superiority of one agent over another 


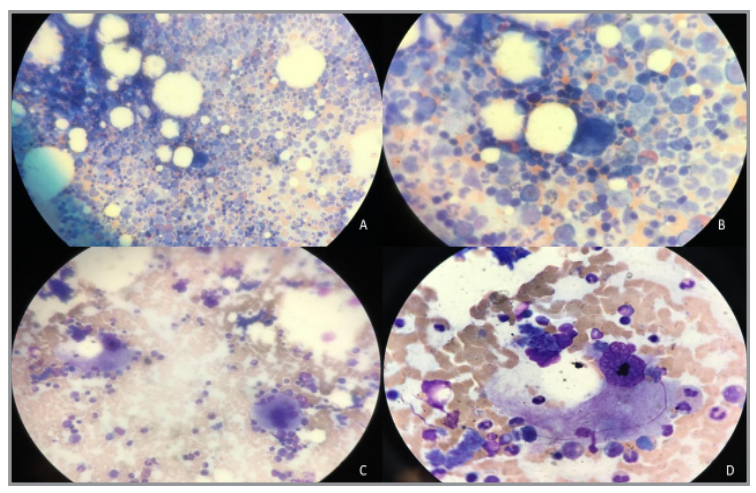

Figure 3. A-B, Bone marrow (BM) megakaryocytes in normal hematopoiesis [BM Aspiration smear, Wright stain, 40x(A) and 100x(B)]. C-D, Neoplastic megakaryocytes of essential thrombocythemia [BM Aspiration smear, Wright stain, 40x(C) and 100x(D)]

are conflicting. Cytoreductive treatment aims at reducing the number of platelets and thus reducing the risk of thromboembolic events, bleeding and preventing the development of AML and myelofibrosis. Anagrelide is a noncytotoxic drug that has been shown to be effective in reducing platelet numbers. Hultdin et al. showed that most of the patients had a complete platelet response to anagrelide treatment, however anagrelide did not prevent the development of fibrosis in patients with ET and polycythemia vera. ${ }^{13}$ Transformation to clinical myelofibrosis was more common in patients treated with anagrelide than with $\mathrm{HU}$ in the recently published study comparing HU versus anagrelide in ET (10). Anagrelide affects the late stages of megakaryocyte development by reducing differentiation. ${ }^{14}$ In contrast to the anagrelide, HU acts on the early phase of megakaryopoiesis and thus reducing proliferation. This could also be the basis for the dysplastic morphology defined in the megakaryopoiesis in HU-treated bone marrows in comparison with anagrelide treated ET patients. ${ }^{15}$

In this study, among the patients we followed with ET, only 1 patient was transformed into AML who treated with HU and anagrelide. Sixteen patients with in the population of $124 \mathrm{ET}$ were observed to have myelofibrosis. Two of these patients were followed up without treatment, 9 patients were treated with HU and 5 patients were treated with HU and anagrelide. However in our study, the relationship

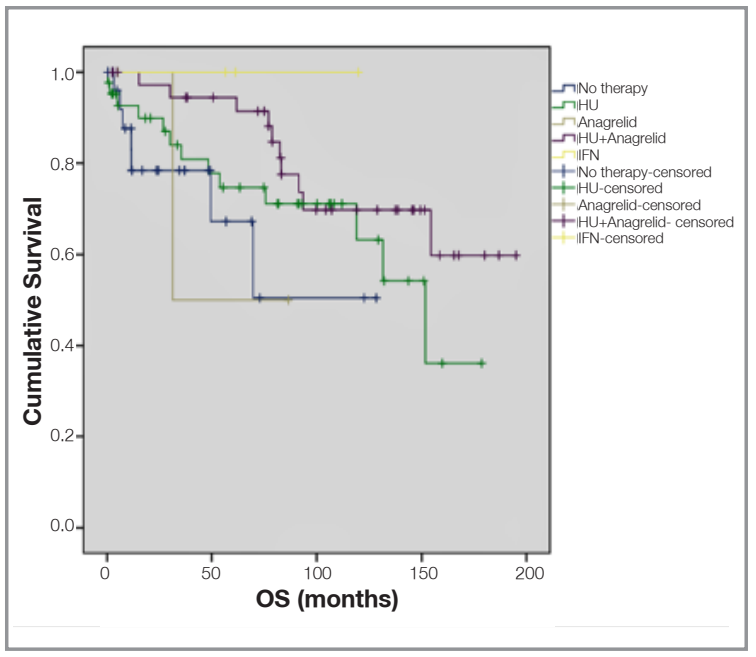

Figure 4. Overall survival according to treatment strategy $(p=0.02)$

between the drugs used in treatment and myelofibrosis development could not be shown. Moreover, an association could not be established between the transformation to AML and drug options. In this study, no difference was observed between the treatment modalities in transforming essential thrombocytosis patients to myelofibrosis, to AML or in developing secondary malignancies. In the previous studies, the risk factors cited for post-ET MF include advanced age, leukocytosis, anemia, reticulin fibrosis, absence of JAK2V617F, use of anagrelide and the presence of ASXL1 mutation. ${ }^{16}$ This study showed that there were an association between the advanced age, anemia, leukocytosis, high CRP level at diagnosis, splenomegaly at diagnosis, high pre-treatment hemorrhage rate and development of myelofibrosis. When those parameters are already high during the initial diagnosis; the patients should be given effective and rapid cytoreductive treatment in order to prevent disease progressing to myelofibrosis. However, there was no statistically significant association between the secondary malignancies and those parameters. There was no statistically significant association between treatment modalities and the risk of secondary malignancy or myelofibrosis development.

The increased risk of developing secondary cancer for the patients with CMPD has been discussed by different studies. Some authors searched for an association with ET therapies and secondary malig- 
nancy while some others searched for the data that could explore a genetic instability of CMPD increasing the susceptibility for the development of secondary malignancies. ${ }^{17-19}$ Moreover, the majority of those studies considered the development of myelodysplastic syndrome or acute leukemia, as a natural evolution of CMPD. ${ }^{20}$ Soyer et al. evaluated 708 patients with CMPD from 9 centers in Turkey. The study showed that six hundred and eight patients $(85.9 \%)$ with CMPD received cytoreductive therapy and most frequently used drug was $\mathrm{HU}$ (89.6\%). The results demostrated that leukemic and fibrotic transformations occurred at rates of $0.6 \%$ and 13.2. ${ }^{21}$ The rates of leukemic and fibrotic transformation were similar to those of our study. Frederiksen et al. showed that the patients with different CMPD were at increased risk of developing both additional hematologic and non-hematologic malignancies. ${ }^{22}$ Finazzi et al. investigated the risk of developing a secondary malignancy among the CMPD patients with 114 ET patients who had received HU with or without busulfan or no chemotherapy at all over a median follow-up period of 73 months. They showed that the difference in cancerfree survival was statistically significant between the $\mathrm{HU}$ and busulfan versus the untreated group $(p<0.0001)$. In our present study, we observed that 3 patients treated with HU suffered of bladder cancer, non-small cell lung cancer and thyroid papillary cancer, 2 patients without treatment suffered of breast cancer and neuroendocrine cancer, 2 patients treated with $\mathrm{HU}$ and anagrelide suffered of AML and prostate cancer. No statistically significant difference was observed between the treatment modalities and the development of secondary malignancies.

The main goal of the treatment is aimed at preventing vascular events that are the leading cause of morbidity and mortality in the CMPD patients. The near normal life expectancy of those patients requires a careful analysis of the benefits and risks associated with treatment essential. Treatment goals in ET are to avoid bleeding and thrombosis, to treat ET related symptoms, improve quality of life and to reduce risk of leukemic transformation and postET myelofibrosis. ${ }^{23}$ This study showed that the patients who received $\mathrm{HU}$ and anagrelide treatment had better OS than the other patients. This finding may prompt us to provide effective cytoreductive treatment to increase the patients' OS.

Our study had a few limitations. First, this study was retrospective. Second the number of patients who treated with only anagrelide or IFN was low. All of the published data support the opinion that patients with CMPD develop secondary malignacy regardless of the treatment modalities given. Important contributing factors for the second cancer risk include intrinsic chronic inflammation and immune dysregulation in the patients with CMPD. In conclusion, among the patients with ET, 16 patients developed myelofibrosis, 1 patient developed AML, and 6 patients developed secondary cancer. This study showed that there was no statistical significant difference between myelofibrosis, AML or secondary malignancy development and treatment modalities. Further prospective clinical trials are needed to fully explore the impact of anagrelide, alpha-interferon and hydroxyurea on the development of bone marrow fibrosis, AML or secondary malignancy in patients with CMPD.

\section{REFERENCES}

1. Samuelson B, Chai-Adisaksopha C, Garcia D. Anagrelide compared with hydroxyurea in essential thrombocythemia: a meta-analysis. J Thromb Thrombolysis 40: 474-479, 2015.

2. Passamonti F, Rumi E, Arcaini L, et al. Prognostic factors for thrombosis, myelofibrosis, and leukemia in essential thrombocythemia: a study of 605 patients. Haematologica 93: 1645-1651, 2008.

3. Cortelazzo S, Viero P, Finazzi G, et al. Incidence and risk factors for thrombotic complications in a historical cohort of 100 patients with essential thrombocythemia. J Clin Oncol 8: 556$562,1990$.

4. Montanaro M, Latagliata R, Cedrone M, et al. Thrombosis and survival in essential thrombocythemia: a regional study of 1,144 patients. Am J Hematol 89: 542-546, 2014.

5. Van Genderen PJ, Perry JJ, Michiels JJ. Erythromelalgia: a pathognomonic microvascular thrombotic complication in essential thrombocythemia and polycythemia vera. Semin Thromb Hemost 23: 357-363, 1997.

6. Colombi M, Radaelli F, Zocchi L, Maiolo AT. Thrombotic and hemorrhagic complications in essential thrombocythemia. A retrospective study of 103 patients. Cancer 67: 2926-2930, 1991.

7. Harrison CN, Bareford D, Butt N, et al. Guideline for investigation and management of adults and children presenting with a thrombocytosis. Br J Haematol 149: 352-375, 2010. 
8. Shvidel L, Sigler E, Haran M, et al. Busulphan is safe and efficient treatment in elderly patients with essential thrombocythemia. Leukemia 21: 2071, 2007.

9. Cortelazzo S, Finazzi G, Ruggeri M, et al. Hydroxyurea for patients with essential thrombocythemia and a high risk of thrombosis. N Engl J Med 332: 1132-1137, 1995.

10. Harrison CN, Campbell PJ, Buck G, et al. Hydroxyurea compared with anagrelide in high-risk essential thrombocythemia. N Engl J Med 353: 33-45, 2005.

11. Group AS. Anagrelide, a therapy for thrombocythemic states: experience in 577 patients. Am J Med 92: 69-76, 1992.

12. Vardiman JW, Thiele J, Arber DA, et al. The 2008 revision of the World Health Organization (WHO) classification of myeloid neoplasms and acute leukemia: rationale and important changes. Blood 114: 937-951, 2009.

13. Hultdin M, Sundström G, Wahlin A, et al. Progression of bone marrow fibrosis in patients with essential thrombocythemia and polycythemia vera during anagrelide treatment. Med Oncol 24: 63-70, 2007

14. Wang G, Franklin R, Hong $Y$, et al. Comparison of the biological activities of anagrelide and its major metabolites in haematopoietic cell cultures. Br J Pharmacol 146: 324-332, 2005.

15. Thiele J, Kvasnicka H, Ollig S, et al. Anagrelide does not exert a myelodysplastic effect on megakaryopoiesis: a comparative immunohistochemical and morphometric study with hydroxyurea. Histol Histopathol 20: 1071-1076, 2005.

16. Cerquozzi S, Tefferi A. Blast transformation and fibrotic progression in polycythemia vera and essential thrombocythemia: a literature review of incidence and risk factors. Blood cancer J 5: e366, 2015.

17. Radaelli F, Onida F, Rossi FG, et al. Second malignancies in essential thrombocythemia (ET): a retrospective analysis of 331 patients with long-term follow-up from a single institution. Hematology 13: 195-202, 2008.
18. Finazzi G, Ruggeri M, Rodeghiero F, et al. Second malignancies in patients with essential thrombocythaemia treated with busulphan and hydroxyurea: long-term follow-up of a randomized clinical trial. Br J Haematol 110: 577-583, 2000.

19. Masarova L, Cherry M, Newberry KJ, et al. Secondary solid tumors and lymphoma in patients with essential thrombocythemia and polycythemia vera-single center experience. Leuk Lymphoma 57: 237-239, 2016.

20. Santoro C, Sperduti I, Latagliata R, et al. Role of treatment on the development of secondary malignancies in patients with essential thrombocythemia. Cancer Med 6: 1233-1239, 2017.

21. Soyer N, Haznedaroglu IC, Comert M, et al. Multicenter retrospective analysis of Turkish patients with chronic myeloproliferative neoplasms. Turk J Hematol 34: 27, 2017.

22. Frederiksen H, Farkas DK, Christiansen CF, et al. Chronic myeloproliferative neoplasms and subsequent cancer risk: a Danish population-based cohort study. Blood 118: 65156520, 2011

23. Haznedaroglu IC. The therapeutic goals of essential thrombocythemia under the clouds of over-treatment and undertreatment. Expert Opin Pharmacother 14: 1411-1436, 2013.

\section{Correspondence:}

Dr. Rafiye ÇIFTÇILER

Hacettepe Üniversitesi, Tip Fakültesi

Hematoloji Anabilim Dali

TR-06100, Sihhiye

ANKARA/ TURKEY

Tel: (+90-505) 5831798

e-mail: rafiyesarigul@gmail.com 